\title{
VALIDATED SPECTROPHOTOMETRIC METHODS FOR THE ESTIMATION OF CINNARIZINE IN BINARY MIXTURE WITH PARACETAMOL IN BULK AND TABLETS
}

\author{
AHMED M AL-GHANI ${ }^{1 *}$, ANES AM THABET ${ }^{2}$ \\ ${ }^{1}$ Department of Pharmaceutical Chemistry and Pharmacy Practice, Medical Sciences College, Al-Razi University, Sana'a, \\ Yemen. ${ }^{2}$ Department of Pharmaceutics and Pharmacy Practice, Medical Sciences College, Al-Razi University, Sana'a, Yemen. \\ Email: gani2010ph@gmail.com
}

Received: 27 November 2020, Revised and Accepted: 14 January 2021

ABSTRACT

Objectives: The aim of this work was to develop and validate new, simple, accurate, and selective spectrophotometric methods (derivative and derivative ratio spectrophotometric methods) for the determination of these drugs. These methods can be used as analytical tools in routine examination in quality control laboratories.

Methods: The first method was derivative method in which the first derivative method ( $\left.{ }^{1} \mathrm{D}\right)$ for determination of PCM and the second derivative method $\left({ }^{2} \mathrm{D}\right)$ for determination of CIN. The second method was the first derivative ratio spectrophotometric method $\left({ }^{1} \mathrm{DD}\right)$ for determination of CIN and PCM.

Results: In first method, the first derivative spectrum ( $\left.{ }^{1} \mathrm{D}\right)$ of PCM where PCM was determined by measuring the amplitude of the valley at 235 nm while CIN showed zero crossing spectrum, and the second derivative spectrum $\left({ }^{2} \mathrm{D}\right)$ of CIN where CIN was determined by measuring the amplitude of the peak at $287.5 \mathrm{~nm}$ while PCM showed a zero value. In the second method, the first derivative ratio spectrophotometry $\left({ }^{1} \mathrm{DD}\right)$ for CIN and PCM determination, where the amplitude at 290 and $291 \mathrm{~nm}$, was selected for the determination of CIN and PCM, respectively.

Conclusions: The developed methods were applied for the determination of the cited drugs in tablets containing binary drug mixture. The methods are simple and precise and can be used for routine analysis of the labeled drugs in combined dosage forms in quality control laboratories.

Keywords: Cinnarizine, Derivative, Derivative ratio, Paracetamol, Spectrophotometry, Validation.

(C) 2021 The Authors. Published by Innovare Academic Sciences Pvt Ltd. This is an open access article under the CC BY license (http://creativecommons.org/ licenses/by/4.0/) DOI: http://dx.doi.org/10.22159/ajpcr.2021v14i3.40384. Journal homepage: https://innovareacademics.in/journals/index.php/ajpcr

\section{INTRODUCTION}

Cinnarizine (CIN) (Fig. 1a), [1-(diphenyl methyl)-3-(4-phenylprop-2enyl)-piperazine] is a piperazine derivative that has antihistaminic (H1 blocker), calcium channel blocker, and sedative activity. CIN is used for the treatment of vertigo, nausea caused by Meniere's disease and motion sickness. In addition, it is used in the various peripheral and cerebral vascular disorders management [1,2]. It is commonly used in combination with other drugs for prophylaxis of vertigo $[1,3]$.

Paracetamol (PCM) (Fig. 1b) is chemically designated as N-[4hydroxyphenyl] acetamide. PCM has antipyretic and analgesic effects and can be used for treatment of mild-to-moderate pain as headaches, fever, and other minor pains and aches. It is also used as a main constituent in several cold medications in combination with nonsteroidal anti-inflammatory drugs [1,4]. PCM acts mainly by inhibition of prostaglandin synthesis in the central nervous system. Such combination is highly effective as each drug potentiates the other in boosting brain oxygen supply.

Literature review revealed that several analytical methods were reported for the spectrophotometric determination of CIN in pharmaceutical preparations and biological fluids. These methods include spectrophotometric [5-19], and spectroflorometric [20-22], voltammetry [23], high-performance liquid chromatography (HPLC) [9,24-41], high-performance thin-layer chromatography (HPTLC) [9,41-45], and capillary electrophoresis [46]. Other methods were developed to determination of CIN in combination with PCM which include spectrophotometry [47], high-performance liquid chromatography (HPLC) and high- performance thin layer chromatography, (HPTLC)[48,49]. However, there is only one UV spectrophotometric method for the determination of CIN in combination with PCM [47]. The aim of the present work was to develop and validate new, selective, accurate, and precise spectrophotometric methods for determination of CIN in binary mixture with PCM in bulk powder and in their pharmaceutical dosage form without the previous separation.

\section{MATERIALS AND METHODS}

\section{Materials and reagents}

PCM and CIN pure standards were supplied by Quality Control Laboratory-Ministry of Health- Sana'a, Yemen, with certified purities of $99.97 \%$, and $99.95 \%$, respectively. The pharmaceutical dosage form was purchased from the Egyptian local market. Cinnarizine ${ }^{\circledR}$ tablets were manufactured by Arab Drug Company Cairo. A.R.E, Batch No. 310363 , each tablet was claimed to contain $20 \mathrm{mg}$ CIN. Paracetamol ${ }^{\circledR}$ tablets were manufactured by (Misr Company for Pharmaceuticals, Batch No. 119026), each tablet was claimed to contain 500 mg PCM. Methanol (analytical grade, Daejung Chemicals \& Metals, Co., Ltd. Korea) was purchased. Distilled water was purchased from Otsuka Pharmaceuticals (Cairo, Egypt).

\section{Instrumentation}

Jenway 6800 Ultraviolet/Visible recording spectrophotometer, U.K. connected to an IBM compatible computer with $1 \mathrm{~cm}$ quartz cell and supported with Jenway Flight Deck software. Ultrasonic processor (Soniclean 120T, Thebarton SA, Australia) was used.

Preparation of stock and working standard solutions Stock solutions

Standard stock solutions of CIN and PCM were separately prepared by accurately transferring $10 \mathrm{mg}$ of each CIN and PCM into two separate 


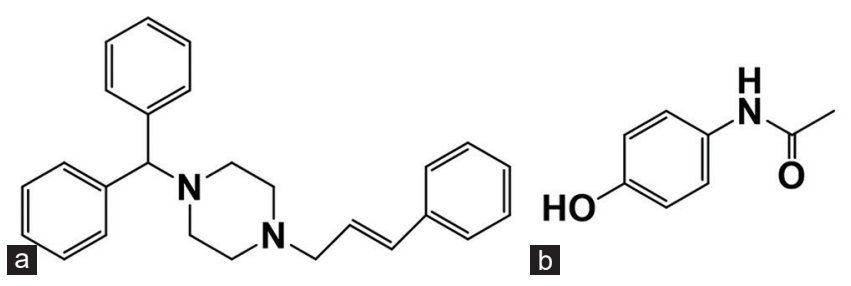

Fig. 1: Chemical structures of (a) cinnarizine and (b) paracetamol

$100 \mathrm{ml}$ volumetric flasks then dissolving in methanol to prepare standard stock solutions of concentration $(1 \mathrm{mg} / \mathrm{ml})$.

\section{Working solutions}

Two aliquots $(10 \mathrm{ml})$ from CIN and PCM standard stock solutions $(1 \mathrm{mg} / \mathrm{ml}$ ) were further diluted to $100 \mathrm{ml}$ with methanol to obtain $100 \mu \mathrm{g} / \mathrm{ml}$ of CIN and PCM as working solutions.

\section{Laboratory prepared mixtures}

Different aliquots of CIN and PCM working solution containing 60-220 $\mu \mathrm{g}$ and 54-102 $\mu \mathrm{g}$ of PCM and CIN, respectively, for ${ }^{1} \mathrm{D}$ and ${ }^{2} \mathrm{D}$ method and 50-200 $\mu \mathrm{g}$ and 50-150 $\mu \mathrm{g}$ of CIN and PCM, respectively, for ${ }^{1} \mathrm{DD}$ method were introduced into two series of $10 \mathrm{ml}$ volumetric flasks.

\section{Sample preparation}

Ten tablets Cinnarizine ${ }^{\circledR}$ and ten paracetamol ${ }^{\circledR}$ tablets were weighed, ground and mixed well. An accurately weighed amount of the powdered tablets equivalent to $10 \mathrm{mg}$ CIN and $250 \mathrm{mg}$ PCM was transferred into a $100 \mathrm{ml}$ volumetric flask. A $50 \mathrm{ml}$ aliquot of methanol was added; the mixture was sonicated for $15 \mathrm{~min}$, cooled and completed to volume with the same solvent. Filtration of the obtained sample stock solution was carried out to obtain sample working solution $(100 \mu \mathrm{g} / \mathrm{ml} \mathrm{CIN} \mathrm{and}$ $2500 \mu \mathrm{g} / \mathrm{ml}$ PCM).

\section{General procedure and linearity}

\section{First and second derivative spectrophotometric methods}

Different aliquots of CIN and PCM working solution containing 40-240 $\mu \mathrm{g}$ of CIN and PCM were introduced into a series of $10 \mathrm{ml}$ volumetric flasks and each flask was completed to volume with methanol. First derivative spectra of PCM were recorded against methanol as blank, using the following instrumental parameters (scaling factor $=1$ and wavelength range $200-400 \mathrm{~nm}$ ). The amplitudes of the valleys at $235 \mathrm{~nm}$ were measured and used for construction of the calibration curve. Second derivative spectra of CIN were recorded against methanol as blank, using the same above instrumental parameters. The amplitude of the peak at $287.5 \mathrm{~nm}$ was measured and used for construction of the calibration curve.

\section{First derivative ratio spectrophotometric method}

Different aliquots of CIN and PCM working solution containing (50-300 $\mu \mathrm{g}$ and 25-150 $\mu \mathrm{g}$ ) of CIN and PCM were introduced into a series of $10 \mathrm{ml}$ volumetric flasks and each flask was completed to volume with methanol. The zero-order spectra were recorded against methanol as blank using the following instrumental parameters for CIN (scaling factor $=100$ and wavelength range $200-400 \mathrm{~nm}$ ) and for PCM (scaling factor = 1 and wavelength range $200-400 \mathrm{~nm}$ ) and stored in the computer. The stored spectra of CIN were divided by the spectrum of selected concentration of PCM $(4 \mu \mathrm{g} / \mathrm{ml})$ to obtain the ratio spectra. Then, the first derivatives of the ratio spectra were obtained using the following instrumental parameters (scaling factor $=100$ and smoothing factor $=50$ ), the amplitudes at $290.0 \mathrm{~nm}$ were measured and used for construction of the calibration curve. The stored spectra of PCM were divided by the spectrum of selected concentration of CIN $(4 \mu \mathrm{g} / \mathrm{ml})$ to obtain the ratio spectra. Then, the first derivatives of the ratio spectra were obtained using the following instrumental parameters (scaling factor $=1$ and smoothing factor $=50$ ), the amplitudes at $291.0 \mathrm{~nm}$ were measured and used for construction of the calibration curve.

\section{Analysis of laboratory prepared mixtures}

The same procedures mentioned under linearity were applied for the determination of CIN and PCM in the laboratory prepared mixtures. The concentrations of CIN and PCM were calculated from the computed regression equations.

\section{Analysis of pharmaceutical formulation}

To estimate the cited drug in mixed Cinnarizine ${ }^{\circledR}$ and paracetamol ${ }^{\circledR}$ tablets, different aliquots were introduced into a series of $10 \mathrm{ml}$ volumetric flasks and each flask was completed to volume with methanol to prepare solutions equivalent to $0.2-0.84 \mu \mathrm{g} / \mathrm{ml}$ of CIN and to $5-21 \mu \mathrm{g} / \mathrm{ml}$ of PCM for first and second derivative method and to $0.16-0.48 \mu \mathrm{g} / \mathrm{ml}$ of CIN and to $4-12 \mu \mathrm{g} / \mathrm{ml}$ of PCM for first derivative ratio method. The same procedures mentioned under linearity were followed. The validity of the methods was evaluated by applying the standard addition technique.

\section{RESULTS AND DISCUSSION}

The ultimate goal of the present work was to develop and validate new, accurate, selective, and precise spectrophotometric methods (first and second derivative and first derivative ratio methods) for the determination of CIN and PCM in binary mixture without previous separation.

\section{Methods development}

By scanning CIN and PCM solution $(10 \mu \mathrm{g} / \mathrm{ml})$ in methanol, over the wavelength range (200-400 $\mathrm{nm})$, a severe overlapping was revealed in their zero-order spectra, Fig. 2.

Derivatization solved such overlap, the first derivative spectrum of PCM in methanol shows a valley at $235.0 \mathrm{~nm}$, where CIN exhibits a zero crossing which could be used for the estimation of PCM, Fig. 3 and the second derivative spectrum of CIN in methanol shows a peak at $287.5 \mathrm{~nm}$, where PCM exhibits a zero value which could be used for the estimation of CIN, Fig. 4 For the ${ }^{1} \mathrm{DD}$, the factors affecting the shape of the ratio spectrum such as the divisor concentration and smoothing factor were investigated.

Different concentrations of CIN for PCM and PCM for CIN $(3,4$, 5 , and $6 \mu \mathrm{g} / \mathrm{ml}$ ) were tried as divisor, a concentration of CIN and also PCM ( $4 \mu \mathrm{g} / \mathrm{ml}$ ) was selected as divisors for each other while the smoothing factor 50 was found to be appropriate. The first derivative ratio spectrum of CIN in methanol shows a peak at 290.0 $\mathrm{nm}$ which could be used for its determination, as showed in Fig. 5 and the first derivative ratio spectrum of PCM in methanol shows a valley at $291.0 \mathrm{~nm}$ which could be used for its determination, as showed in Fig. 6.

\section{Methods validation}

Methods validation was achieved in accordance with International Conference on Harmonization guidelines [50].

\section{Linearity}

Linear relationships were obtained over the concentration ranges of $4-24 \mu \mathrm{g} / \mathrm{ml}$ for CIN and PCM ( ${ }^{1} \mathrm{D}$ and ${ }^{2} \mathrm{D}$ method) and $5-30 \mu \mathrm{g} / \mathrm{ml}$ for CIN and $2.5-15.0 \mu \mathrm{g} / \mathrm{ml}$ for PCM for ${ }^{1} \mathrm{DD}$ methods. The regression equations were computed and validation data are summarized in Tables 1 and 2 .

\section{Accuracy}

The accuracy of the developed methods was established by analyzing pure samples of the cited drugs. The accuracy was expressed as \% recovery by calculation of concentration from regression equations (Tables 1 and 2). In addition, accuracy was further tested by applying the standard addition technique on mixed Cinnarizine ${ }^{\circledR}$ and Paracetamol ${ }^{\circledR}$ tablets. Good recoveries were obtained, revealing 


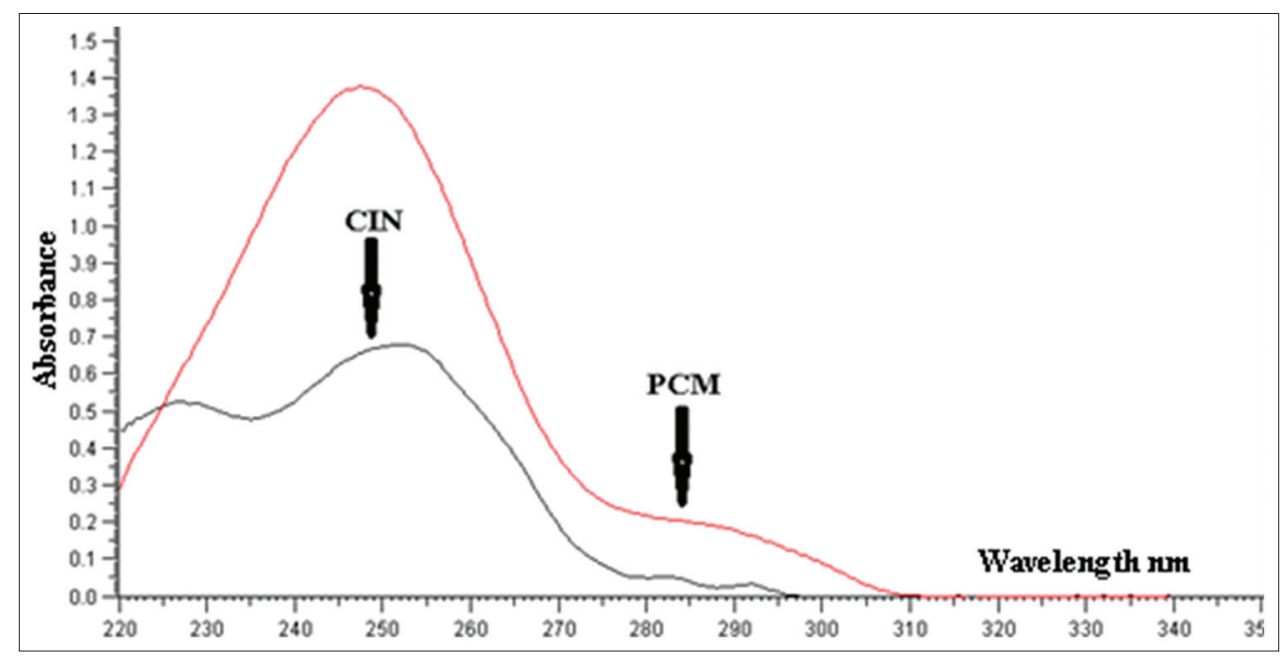

Fig. 2: Zero-order absorption spectra of PCM $(8 \mu \mathrm{g} / \mathrm{ml})$ and CIN $(8 \mu \mathrm{g} / \mathrm{ml})$ in methanol

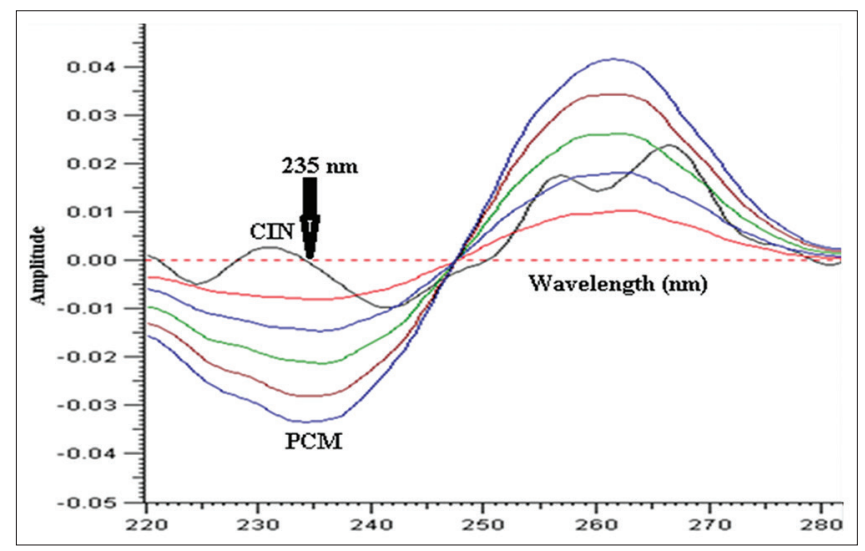

Fig. 3: First derivative spectra of PCM $(4-24 \mu \mathrm{g} / \mathrm{ml})$ and CIN $(8 \mu \mathrm{g} / \mathrm{ml})$ in methanol

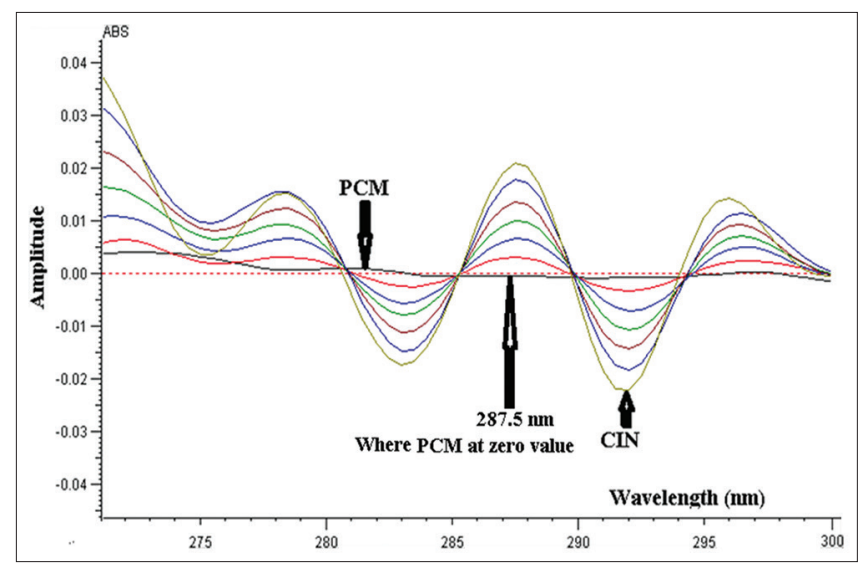

Fig. 4: Second derivative spectra of CIN $(4-24 \mu \mathrm{g} / \mathrm{ml})$ and PCM $(8 \mu \mathrm{g} / \mathrm{ml})$ in methanol

no interference from excipients and good accuracy of the proposed methods, Tables 1 and 2.

\section{Precision}

The analytical methods precision provided a satisfactory intraday and interday study. In intraday, the same three concentrations for two drugs $(6,12$, and $22 \mu \mathrm{g} / \mathrm{ml})$ for first derivative $\left({ }^{1} \mathrm{D}\right)$ for

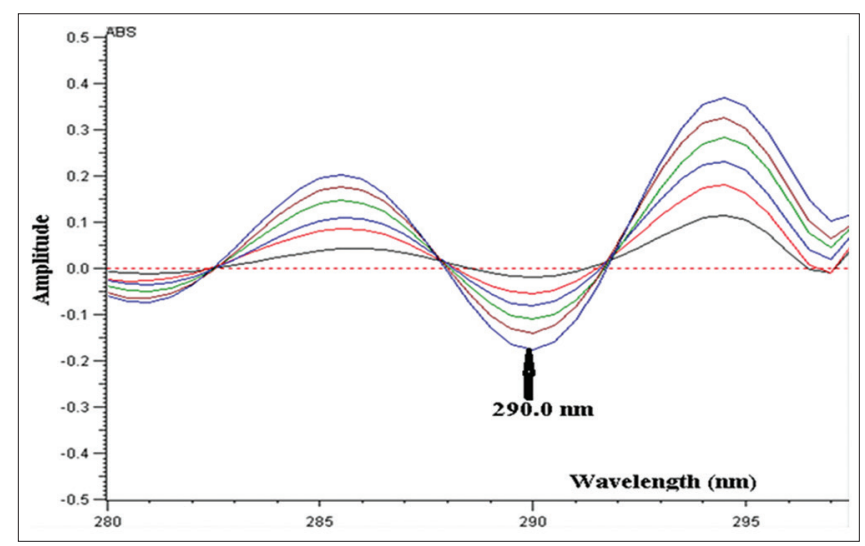

Fig. 5: The first derivative ratio spectra ( $\left.{ }^{1} \mathrm{DD}\right)$ of different concentrations of CIN working solution $(5-30 \mu \mathrm{g} / \mathrm{ml})$ in methanol (divisor: $4 \mu \mathrm{g} / \mathrm{ml} \mathrm{PCM}$ ) at $290.0 \mathrm{~nm}$

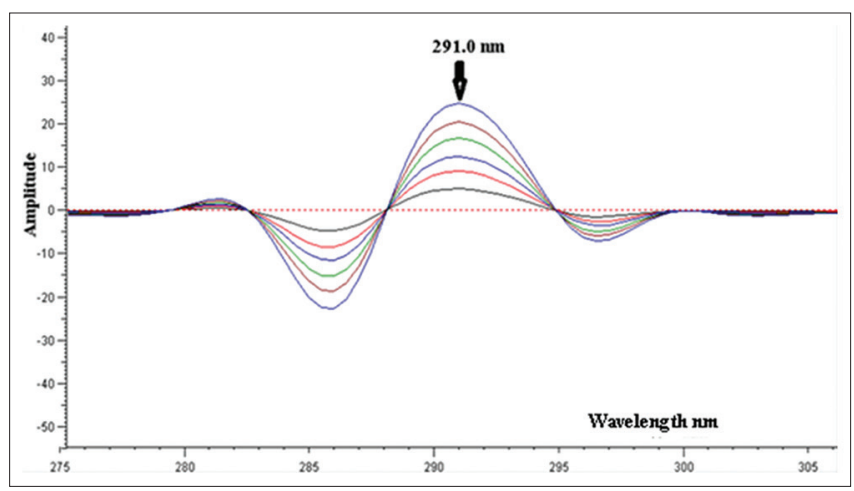

Fig. 6: The first derivative ratio spectra ( $\left.{ }^{1} \mathrm{DD}\right)$ of different concentrations of PCM working solution $(2.5-15.0 \mu \mathrm{g} / \mathrm{ml})$ in methanol (divisor: $4 \mu \mathrm{g} / \mathrm{ml} \mathrm{CIN)}$ ) at $291.0 \mathrm{~nm}$

paracetamol (PCM) and second derivative $\left({ }^{2} \mathrm{D}\right)$ for cinnarizine (CIN). Furthermore, three concentrations of CIN $(6,12$, and $22 \mu \mathrm{g} /$ $\mathrm{ml})$ and three concentrations of PCM $(4,9$, and $14 \mu \mathrm{g} / \mathrm{ml})$ for ${ }^{1} \mathrm{DD}$ were analyzed 3 times during the same day using the developed methods. For intermediate precision, the developed methods were repeated on 3 successive days for the analysis of the previously mentioned drug concentrations. The obtained results and RSD \% 
values were satisfactory indicating good precision of the developed methods, Tables 1 and 2 .

Limit of detection (LOD) and limit of quantification (LOQ)

The LOD and LOQ were calculated based on standard deviation (SD) of the response and slope, where $\mathrm{LOQ}=10 \times \mathrm{SD} /$ slope and $\mathrm{LOD}=3.3 \times \mathrm{SD} /$ slope. The low value of LOD and LOQ confirm the high sensitivity of the developed methods, Tables 1 and 2 .

\section{Statistical analysis}

All results obtained from the proposed methods were statistically compared with those obtained from reported RP-HPLC method [9], and spectrophotometric method [51]. The student $\mathrm{t}$-test and $\mathrm{F}$ ratio test were applied; the obtained values of $\mathrm{t}$ and $\mathrm{F}$ were less than the tabulated ones, confirming that the difference between the developed and reported methods is insignificant in terms of accuracy and precision, Table 3.

Table 1: Validation parameters and results obtained by the first derivative and second derivative spectrophotometric methods for the determination of CIN and PCM

\begin{tabular}{|c|c|c|}
\hline Item & $\begin{array}{l}\text { The proposed first derivative } \\
\text { spectrophotometric method (PCM) }\end{array}$ & $\begin{array}{l}\text { The proposed second derivative } \\
\text { spectrophotometric method (CIN) }\end{array}$ \\
\hline Solvent used & Methanol & Methanol \\
\hline$\lambda_{\max }$ of measurement & $235.0 \mathrm{~nm}$ & $287.5 \mathrm{~nm}$ \\
\hline Linearity range & $4-24 \mu \mathrm{g} / \mathrm{ml}$ & $4-24 \mu \mathrm{g} / \mathrm{ml}$ \\
\hline $\mathrm{LOD}(\mu \mathrm{g} / \mathrm{ml})$ & 0.499 & 0.407 \\
\hline $\mathrm{LOQ}(\mu \mathrm{g} / \mathrm{ml})$ & 1.508 & 1.233 \\
\hline Regression equation & Amp $235.0 \mathrm{~nm}=0.015 \mathrm{C}_{\mathrm{PCM}}-0.0009$ & Amp $287.5 \mathrm{~nm}=0.0071 \mathrm{C}_{\mathrm{CIN}}-0.008$ \\
\hline Standard error of estimation & 0.00295 & 0.00057 \\
\hline Standard deviation of slope $S_{b}$ & 0.00017 & 0.00034 \\
\hline Standard deviation of intercept $\mathrm{S}_{\mathrm{a}}$ & 0.00274 & 0.00053 \\
\hline Confidence limit of the slope & $0.015 \pm 0.0005$ & $0.0071 \pm 0.0001$ \\
\hline Confidence limit of the intercept & $0.0009 \pm 0.0067$ & $0.0079 \pm 0.0015$ \\
\hline \multicolumn{3}{|l|}{ Intraday precision* } \\
\hline RSD $\%$ & $0.469-0.787$ & $0.636-1.274$ \\
\hline \multicolumn{3}{|l|}{ Interday precision $* *$} \\
\hline \multicolumn{3}{|l|}{ Results } \\
\hline Recovery \% in drug substance & $100.13 \pm 0.458$ & $100.73 \pm 0.833$ \\
\hline Recovery \% in laboratory prepared mixtures & $100.48 \pm 0.503$ & $100.66 \pm 0746$ \\
\hline Recovery \% in (Cinnarizine ${ }^{\circledR}$ \& Paracetamol $^{\circledR}$ ) dosage form & $100.58 \pm 0.533$ & $100.84 \pm 0.972$ \\
\hline Recovery $\%$ of drug added & $99.18 \pm 1.113$ & $99.59 \pm 1.381$ \\
\hline
\end{tabular}

*The intraday ( $\mathrm{n}=3)$, average of three concentrations $(6,12$, and $22 \mu \mathrm{g} / \mathrm{ml})$ of PCM and CIN products repeated 3 times in the same days. ${ }^{* *}$ The interday ( $\left.\mathrm{n}=3\right)$, average of three concentrations $(6,12$, and $22 \mu \mathrm{g} / \mathrm{ml})$ of PCM and CIN products repeated 3 times in three successive days

Table 2: Validation parameters and results obtained by the first derivative ratio spectrophotometric methods for the determination of CIN and PCM

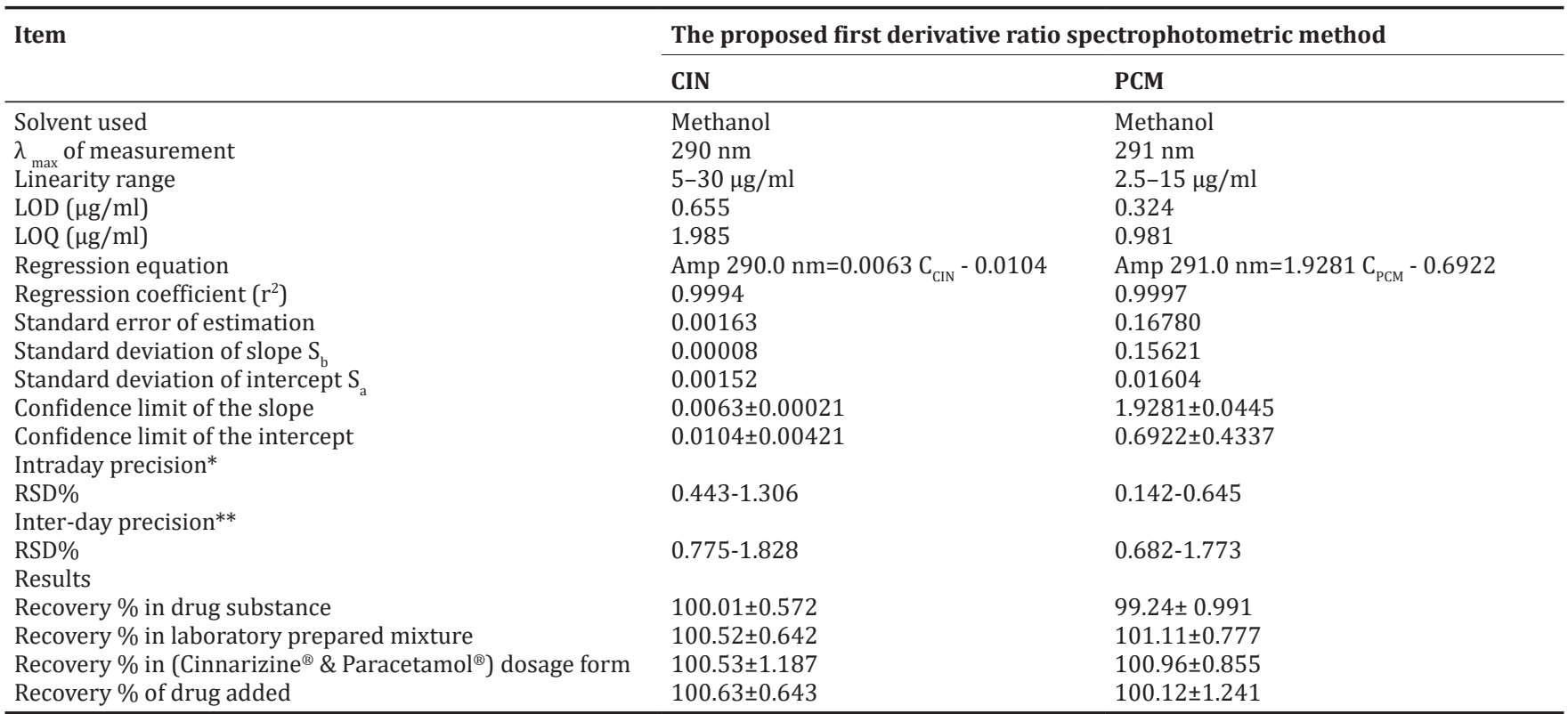

*The intraday $(\mathrm{n}=3)$, average of three concentrations $(6,12$, and $22 \mu \mathrm{g} / \mathrm{ml})$ of CIN and $(4,9,14)$ of PCM products repeated 3 times in the same days. ${ }^{* *}$ The interday $(\mathrm{n}=3)$, average of three concentrations $(6,12$, and $22 \mu \mathrm{g} / \mathrm{ml})$ of CIN and $(4,9$, and 14$)$ of PCM products repeated 3 times in three successive days 
Table 3: Tests of significance for the developed first derivative, second derivative, and first derivative ratio spectrophotometric methods for the determination of CIN and PCM

\begin{tabular}{|c|c|c|c|c|c|c|}
\hline \multirow{2}{*}{$\begin{array}{l}\text { Statistical } \\
\text { term }\end{array}$} & \multicolumn{3}{|l|}{ CIN } & \multicolumn{3}{|l|}{ PCM } \\
\hline & $\begin{array}{l}\text { Reference } \\
\text { method }^{* *}\end{array}$ & $\begin{array}{l}\text { Second derivative } \\
\text { spectrophotometric } \\
\text { method }\end{array}$ & $\begin{array}{l}\text { First derivative ratio } \\
\text { spectrophotometric } \\
\text { method }\end{array}$ & $\begin{array}{l}\text { Reference } \\
\text { method }^{* * *}\end{array}$ & $\begin{array}{l}\text { First derivative } \\
\text { spectrophotometric } \\
\text { method }\end{array}$ & $\begin{array}{l}\text { First derivative ratio } \\
\text { spectrophotometric } \\
\text { method }\end{array}$ \\
\hline Mean & 100.48 & 100.73 & 100.01 & 100.11 & 100.13 & 99.24 \\
\hline$\pm \mathrm{SD}$ & 0.536 & 0.833 & 0.572 & 0.76 & 0.458 & 0.991 \\
\hline$\pm \mathrm{SE}$ & 0.24 & 0.373 & 0.256 & 0.34 & 0.205 & 0.443 \\
\hline RSD\% & 0.534 & 0.827 & 0.572 & 0.759 & 0.458 & 0.999 \\
\hline $\mathrm{N}$ & 5 & 5 & 5 & 5 & 5 & 5 \\
\hline V & 0.288 & 0.695 & 0.327 & 0.577 & 0.21 & 0.982 \\
\hline $\mathrm{t}(2.306)^{*}$ & & 0.558 & 1.342 & & 0.055 & 1.547 \\
\hline $\mathrm{F}(6.388)^{*}$ & & 2.416 & 1.135 & & 2.746 & 1.702 \\
\hline
\end{tabular}

SD: Standard deviation, SE: Standard error, RSD: Relative standard deviation. *Figures in parentheses are the theoretical t and $\mathrm{F}$ values at ( $\mathrm{p}=0.05)$. ${ }^{* *}$ Metwally et al. RP-HPLC method [9]. *** USP 2016: Spectrophotometric method [51]

\section{CONCLUSION}

The developed spectrophotometric methods for the estimation of CIN and PCM in combination are selective, sensitive, accurate, and precise. The methods were validated and successfully applied for the determination of the cited drugs in pharmaceutical formulation. They can be used for the routine analysis of these drugs in quality control laboratories.

\section{ACKNOWLEDGEMENT}

The authors are thankful for center of Scientific Research and Researchers' Al-Razi University for its support

\section{AUTHORS' CONTRIBUTIONS}

The correspondent author conceived the idea and developed the theory and performed the calculations of the presented work. All authors participated in conducting experiments, discussing the results, and contributing to the last manuscript.

\section{CONFLICTS OF INTEREST}

The authors declare that there are no conflicts of interest of publishing this article.

\section{AUTHORS FUNDING}

There is no any funding.

\section{REFERENCES}

1. O'Neil MJ, Heckelman P, Koch C, Roman K. The Merck Index. $14^{\text {th }}$ ed. Whitehouse Station, NJ: Merck; 2006.

2. Sweetman SC. Martindale: The Complete Drug Reference. $36^{\text {th }}$ ed. London, United Kingdom: Pharmaceutical Press; 2011.

3. Rang H, Dale M, Ritter J, Moore P. Pharmacology. Vol. 5. Edinburgh: Churchill Livingstone; 2003. p. 1084.

4. Cormie P, Nairn M, Welsh J. Guidelines: Control of pain in adults with cancer: Summary of SIGN guidelines. BMJ 2008;337:1106-9.

5. Abdine H, Belal F, Zoman N. Simple spectrophotometric determination of cinnarizine in its dosage forms. Il Farmaco 2002;57:267-71.

6. Salem MY, El-Bardicy MG, El-Tarras MF, El-Zanfally ES. Simultaneous determination of domperidone maleate and cinnarizine in a binary mixture using derivative ratio spectrophotometry and classical least squares calibration. J Pharm Biomed Anal 2002;30:21-33.

7. Vinodhini C, Vaidhyalingam V, Ajithadas A, Shantha A. Simultaneous estimation of cinnarizine and domperidone in solid oral dosage form using spectrophotometric method. Indian Drugs 2002;39:491-3.

8. Salem MY, El-Zanfaly ES, El-Tarras MF, El-Bardicy MG. Simultaneous determination of domperidone and cinnarizine in a binary mixture using derivative spectrophotometry, partial least squares and principle component regression calibration. Anal Bioanal Chem 2003;375:211-6.

9. Metwally FH, Elzeany B, Darwish H. New methods for determination of cinnarizine in mixture with piracetam by spectrodensitometry, spectrophotometry, and liquid chromatography. J AOAC Int 2005;88:1666-76.

10. Zayed S. Simultaneous determination of cinnarizine and nicergoline in a binary mixture using first derivative spectra, first derivative of ratio spectra and multivariate calibration techniques. J Anal Chem 2010;65:921-8.

11. Shah PB, Patel PU. Q-absorbance ratio spectrophotometric method for the simultaneous estimation of cinnarizine and dimenhydrinate in their combined dosage form. J Pharm Sci Biosci Res 2012;2:83-7.

12. Tarkase K, Tarkase M, Dokhe M, Wagh V. Development and validation of spectrophotometric method for simultaneous estimation of cinnarizine and domperidone maleate in pure and tablet dosage form. Int J Pharm Sci Res 2012;3:2700-4.

13. Abdelrahman MM. Simultaneous determination of cinnarizine and domperidone by area under curve and dual wavelength spectrophotometric methods. Spectrochim Acta A Mol Biomol Spectrosc 2013;113:291-6.

14. Kalyankar T, Wadher S, Kulkarni P, Panchakshari P. Simultaneous estimation and development of UV spectroscopic method for determination of cinnarizine and domperidone in bulk and pharmaceutical formulation. Int J PharmTech Res 2014;6:323-9.

15. Lamie T. Simultaneous determination of cinnarizine and dimenhydrinate in binary mixture using, first derivative of ratio spectra and bivariate spectrophotometric techniques. Anal Chem Indian J 2014;14:93-9.

16. Lamie NT. Comparative study of spectrophotometric methods manipulating ratio spectra: An application on pharmaceutical binary mixture of cinnarizine and dimenhydrinate. Spectrochim Acta A Mol Biomol Spectrosc 2015;141:193-201.

17. Lamie NT, Yehia AM. Development of normalized spectra manipulating spectrophotometric methods for simultaneous determination of dimenhydrinate and cinnarizine binary mixture. Spectrochim Acta A Mol Biomol Spectrosc 2015;150:142-50.

18. Tawakkol SM, El-Zeiny MB, Hemdan A. Full spectrum and selected spectrum based chemometric methods for the simultaneous determination of cinnarizine and dimenhydrinate in laboratory prepared mixtures and pharmaceutical dosage form. Spectrochim Acta A Mol Biomol Spectrosc 2017;173:892-6.

19. Al-Ghani AM, Thabit AA, Albaser N. Simultaneous spectrophotometric estimation of cinnarizine in binary mixture with piracetam in bulk and pharmaceutical dosage forms. World J Pharm Res 2020;9:2099-113.

20. Niu SY, Wang SJ, Shi C, Zhang SS. A rapid, simple and highly sensitive second derivative synchronous fluorometric method has been developed for the simultaneous analysis of binary mixture of cinnarizine $(\mathrm{CN})$ and domperidone (DOM). J Fluoresc 2008;18:227-35.

21. Walash M, Belal F, El-Enany N, Abdelal A. Second-derivative synchronous fluorometric method for the simultaneous determination of cinnarizine and domperidone in pharmaceutical preparations. Application to biological fluids. J Fluoresc 2008;18:61-74.

22. Walash MI, Belal F, El-Enany N, Abdelal A. Second-derivative synchronous fluorescence spectroscopy for the simultaneous determination of cinnarizine and nicergoline in pharmaceutical preparations. J AOAC Int 2008;91:349-59.

23. El-Sayed G, Yasin S, El Badawy A. Voltammetric behavior and determination of cinnarizine in pharmaceutical formulations and serum. Anal Lett 2008:41:3021-33. 
24. Hundt H, Brown L, Clark E. Determination of cinnarizine in plasma by high-performance liquid chromatography. J Chromatogr 1980;183:378-82.

25. Nitsche V, Mascher H. Rapid high-performance liquid chromatographic assay of cinnarizine in human plasma. J Chromatogr 1982;227:521-5.

26. Rosseel M, Lefebvre R. Sensitive determination of cinnarizine in human plasma by high performance liquid chromatography and fluorescence detection. Chromatographia 1993;36:356-8

27. Argekar A, Shah S. Simultaneous determination of cinnarizine and domepiridone maleate from tablet dosage form by reverse phase ion pair high performance liquid chromatography. J Pharm Biomed Anal 1999;19:813-7.

28. Angelov T. High-performance liquid chromatographic determination of cinnarizine in workplace air. Chromatographia 2003;58:483-5.

29. Nowacka-Krukowska H, Rakowska M, Neubart K, Kobylińska M. High-performance liquid chromatographic assay for cinnarizine in human plasma. Acta Pol Pharm Drug Res 2007;64:407-11.

30. Heda A, Sonawane A, Naranje G, Puranik P. A rapid determination of cinnarizine in bulk and pharmaceutical dosage form by LC. J Chem 2010;7:1080-4.

31. El-Houssini OM, Zawilla NH, Mohammad MA. Development and validation of RP-LC method for the determination of cinnarizine/ piracetam and cinnarizine/heptaminol acefyllinate in presence of cinnarizine reported degradation products. Anal Chem Insights 2013;8:99-106.

32. Kumari S, Naga S. Validated RP-HPLC method for simultaneous estimation of cinnarizine and domperidone in bulk and pharmaceutical dosage form. J Pharm Sci Innov 2013;2:46-50.

33. Navaneethan G, Karunakaran K, Elango K. Stability indicating and simultaneous determination of cinnarizine and piracetam from capsule dosage form by reversed phase high performance liquid chromatography. Indian J Chem Technol 2013;20:323-6.

34. Prahalad R, Rao RN, Konam K, Edara SR, Rathna T. Method development and validation for the simultaneous estimation of domperidone maleate and cinnarizine in a pharmaceutical formulation by Rp-Hplc method. Indo Am J Pharm Res 2013;3:8111-20.

35. Kalyankar T, Kulkarni P, Panchakshari P, Narute A. Simultaneous RP-HPLC estimation of cinnarizine and domperidone in tablet. Res J Pharm Technol 2014;7:650-4.

36. Khushbu S, Pinkal P. Development and validation of analytical method for simultaneous estimation of cinnarizine and dimenhydrinate in tablet dosage form. Int J Pharm Sci Res 2014;5:4815-9.

37. Abdelwahab NS, Abdelrahman MM, Salama FM, Ahmed AB. Determination of dimenhydrinate and cinnarizine in combined dosage form in presence of cinnarizine impurity. Eur J Chem 2015;6:475-81.

38. Sunitha KS. Method development and validation for simultaneous estimation of domperidone maleate and cinnarizine by RP-HPLC. Int J Pharm Anal Res 2015;4:183-92.

39. Lamie NT, Monir HH. Simultaneous determination of cinnarizine and dimenhydrinate in binary mixture using chromatographic methods. J Chromatogr Sci 2016;54:36-42.

40. SM EA, Hasan MH. Exploring novel isocractic HPLC method for quantitative determination of cinnarizine and piracetam in their capsule preparations. J Appl Pharm 2016;8:1-5.

41. Ahmed AB, Abdelwahab NS, Abdelrahman MM, Salama FM. Simultaneous determination of dimenhydrinate, cinnarizine and cinnarizine impurity by TLC and HPLC chromatographic methods. Bull Fac Pharm Cairo Univ 2017;55:163-9.

42. Argekar A, Powar S. Simultaneous HPTLC determination of cinnarizine and domperidone maleate in formulations. J Planar Chromatogr 1999;12:272-4.

43. Bagade S, Walode S, Charde M, Tajne M, Kasture A. Simultaneous HPTLC estimation of cinnarizine and domperidone in their combined dose tablet. Asian J Chem 2005;17:1116-26.

44. El-Kafrawy DS, Belal TS. Validated HPTLC method for the simultaneous determination of cinnarizine and dimenhydrinate in their combined dosage form. J Asso Arab Univ Basic Appl Sci 2016;19:15-22.

45. Shirode AR, Ghuge AD, Kadam VJ. HPTLC method development and validation of cinnarizine in bulk and marketed formulation. Int J Pharm Sci Res 2016;7:2416-22

46. Abdelal A, Kitagawa S, Ohtani H, El-Enany N, Belal F, Walash M. Method development and validation for the simultaneous determination of cinnarizine and co-formulated drugs in pharmaceutical preparations by capillary electrophoresis. J Pharm Biomed Anal 2008;46:491-7.

47. Ahmed R, Supriya RS, Sheetal DR. Spectrophotometric method for simultaneous estimation of paracetamol and cinnarizine in tablet dosage forms. Res J Pharm Tech 2012;5:667-71.

48. Chauhan RJ, Master SM, Pasha T, Thakor KA, Patel PU. Development and validation of RP-HPLC method for simultaneous estimation of cinnarizine and paracetamol in their pharmaceutical dosage form. Int Bull Drug Res 2014;4:41-52.

49. Mahrouse MA, El-Zaher AA, Al-Ghani AM. Validated chromatographic methods for simultaneous estimation of cinnarizine in binary mixture with domperidone and paracetamol in tablets. Curr Pharm Anal 2019; $15: 429-38$

50. Branch SK. Guidelines from the international conference on harmonisation (ICH). J Pharm Biomed Anal 2005;38:798-805.

51. Pharmacopeia Commission. The United States Pharmacopeia (USP 39), (NF 34) National Formulary. Washington, DC, Rockville, MD: United States Pharmacopeia Commission; 2016. 